\title{
THE INTERSTATE COMMERCE COMMISSION BEFORE THE FEDERAL COURTS.
}

By Cratwford Heistg.

The Interstate Commerce Commission, created by the Act of February 4, I887 (commonly known as the Interstate Commerce Act), appears as plaintiff in several suits now pending before the Federal Courts, instituted to enforce the orders of the Commission.

There results from this litigation a number of judicial decisions upon important questions of constitutional law and the law of interstate commerce affecting the powers and duties of the Commission and the rights and remedies of parties complaining of violations of the act. Though none of these cases has been passed upon by the Supreme Court, the uniformity of the decisions rendered by the Circuit Courts upon many points indicates the trend of judicial opinion and foretells the judgment of the final authority.

The grave importance of these questions to the business interests and transportation agencies of the country invites an examination of the legal questions at issue, with the view of so modifying the existing statute as to harmonize its provisions with the decisions of the judiciary and the exigencies of the case.

I. What effect and weight are due to the findings of fact of the Interstate Commerce Commission, wohen the same are duly ascertained, reported in writing, and, having been duly certified, are offered in evidence in subsequent judicial proceedings in the Circuit. Courts, according to Section 14 of the act?

This point has been uniformly decided by three, at least, of the Circuit Courts. ${ }^{1}$ In all of these cases the findings of the Commission have been totally ignored, and the party seeking relief compelled to produce his evidence

\footnotetext{
${ }^{1}$ Kentucky \& Indiana Bridge Co. $v$. I. \& N. R. R. Co., 37 F. R., 567 ; Interstate Commerce Commission $v$. R. \& O. R. R., 43 F. R., 48 ; Interstate Commerce Commission v. I. V. R. R. (not yet reported).
} 
de novo before the Circuit Court. In the first two instances cited the decision of the Commission has been reversed and their order revoked.

In the case of the Interstate Commerce Commission $v$. Lehigh Valley Railroad Co., a motion was made for a preliminary injunction to enforce the order of the Commission as based upon its findings of fact. The Court, through an opinion by Judge ACFESON, decided that the motion must be denied. At present, it is a sufficient statement of the facts of this case to say that at the complaint of Coxe Bros. \& Co. against the Lehigh Valley Railroad Co., filed October 19, I888, an investigation was begun, and the railroad company having answered the complaint, the Commission devoted five days to hearing testimony and two days to hearing argument; that on March I3, I89I, the Commission made a report in writing of the findings of fact; and decided that the rates charged complainant by the defendant for transporting coal from the anthracite regions of Penusylvania to Perth Amboy, N. J., were unjust and unreasonable and in violation of the first section of the act to regulate commerce; that an order was made on the defendant corporation to "wholly cease from charging any greater compensation for the transportation of divers known kinds and sizes of anthracite coal from the Lehigh anthracite coal regions of Pennsylvania to Perth Amboy, N. J., than certain maximum rates fixed by the Commission in its order; that the petition filed by the Commission in the Federal Court includes a certified copy of the report of the findings of fact, together with the order made upon the defendant; that the answer of the Lehigh Valley Railroad Co. admits explicitly that the order was made on the defendants as alleged, and that it had refused compliance;" but the answer averred "that the findings of fact upon which the Commission based its decision that the charges to Perth Amboy, N. J., from the coal regions of Pennsylvania were unjust and unreasonable were not in accordance with the evidence or with the law."

An examination of the statute leaves no room for doubt that the decision of the Court upon this record, however 
fatal to the efficiency of the Commission, was, nevertheless, a correct interpretation of the existing law. Section I4 of the statute declares that the findings of fact of the Commission "shall thereafter, in all judicial proceedings, be deemed prima-facie evidence as to each and every fact found." "What is prima-facie evidence?" asks Mr. Justice STORY, in Kelly v. Jackson." "It is," he observes, "such as in judgment of law is sufficient to establish the fact, and, if not rebutted, remains sufficient for the purpose." The counsel for the Commission endearored, in their argument, to confound prima-facie evidence with conclusive evidence. They further endeavored to give to these findings the effect of a judicial judgment. "Every judgment is conclusive proof as against parties and privies of facts directly in the case actually decided by the Court, and appearing from the judgment itself to be the ground on which it was based." 2 If Congress had intended that the decision of the Commission should have the effect of a judgment, it would not have used language which contemplates a subsequent trial of the case upon its merits, in which the findings of the Commission are to have the weight of prima-facie evidence. The argument of Mr. Sterne (of counsel for the Commission), that the only facts re-triable by the Circuit Court are "(I) Jurisdictional questions of whether the defendant has been properly served; (2) jurisdictional questions of whether the subjectmatter is within the cognizance of the Commission; (3) the issue of fact, whether the order has been obered or disobeyed," is negatived by the words of the act itself, which makes no distinction between the effect of facts found, but makes the findings of the Commission "prima-facie" evidence " as to each and every fact found." Moreover, the act clearly provides for a re-trial of all the facts before the $\mathrm{Cir}$ cuit Court. Section I 8 empowers the Court, "if it think fit, to direct and prosecute in such mode and by such persons as it may appoint, all such inquiries as the Court may think needful to enable it to forn a just judgment in the

16 Peters, 632.

'Stephen on Evidence, p. $\$ 7$. 
matter of such petition, and on such hearing the findings of fact in the report of said Commission shall be primafacie evidence of the matters therein stated." Nor is the distinction tenable between the effect of these findings when offered as evidence by a shipper seeking to enforce an order of the Commission in his favor, and the effect of these findings when offered by the Commission itself. The same words of the act grammatically apply to both cases, and in neither case have the findings more weight than that of prima-facie evidence, whose effect is merely to transfer the burden of proof from the plaintiff to the defendant. ${ }^{1}$

The argument that the Commission is a court, and that, therefore, its decisions are conclusive like the judgments of a sister State, has been regarded with little favor by the Federal judges. In Kentucky \& Indiana Bridge Co. v. L. \& N. R. R. Co., supra, Judge JAckson held that the Commission is merely a referee of the Circuit Court, and in support of this position he argues that the Commission cannot be a court constitutionally organized, because its members hold only for a fixed period, and not during good behavior. Congress may, however, create legislative courts exercising administrative power only, and whose judges, being invested with none of the judicial power of the United States, may hold office otherwise than during good behavior. ${ }^{2}$

"Notwithstanding the judge's misconception of a point of constitutional law," to use Mr. Sterne's expression, "the conclusion is apparent that the effects of the decisions of a 'legislative court' are necessarily conclusive, but are controlled by the terms of the act creating it." "If," says Judge ACHESON, in Interstate Commerce Commission v. Lehigh. Valley Railroad Co., "the acts of Congress had been silent as to the effect to be given to findings of fact by the Interstate Commerce Commission, it might, perhaps, have been reasonably inferrable that the legislative intent was that those findings should fall within the general rule, that

1 See also State ex rel. Board of Transportation $v$. Freemont, E. \& M. R. R. Co., 35 Fed. Reporter, Ir8.

${ }^{2}$ American Insurance Co. $v$. Canter, I Peters, 5 Ir. 
where the law has confided to a special tribunal the authority to hear and determine certain matters in the course of its duties, the decision of that tribunal, within the scope of its authority, is conclusive upon all other tribunals, but any such implication is excluded by the express terms of the Interstate Commerce Act."

The true construction of the meaning of the law upon this point may, therefore, be summed up in the opinion of Judge Achesox: "That the Court is not confined to a mere examination of the acts, as heard and reported by the Commissioners, but hears and determines the case, de nov'o, upon proper pleadings and proof that include, not only the prima-facie facts reported by the Commission, but all other and further testimony as either party may introduce bearing upon the matters in controversy."

The practical effects of this interpretation are such as to clearly demand an amendment to the act. The question naturally arises, Will shippers make complaints to the Commission as heretofore, or will they proceed in the first instance to endeavor to enforce their rights in the Federal Courts? If the first course be adopted, complaints are involved in the expense, labor and delay of twice presenting their testimony, and that, too, with no compensating advantages. Experience shows that a favorable decision by the Commission, and the offering of its findings of facts as eridence in the Circuit Court, is of no practical assistance. Moreover, questions as to the propriety of railroad rates relate only to present conditions, and a decision, to be of any value, must be rendered without delay. If, on the other hand, the Circuit Courts have jurisdiction to enforce, by injunction, not merely the lawful orders of the Commission, but also the provision of the act independently of a previous complaint to that body, shippers will obtain redress in the Federal Courts in the first instance. The Interstate Commerce Commission will become a nonentity, and the Federal Courts will be compelled to decide a multitude of railroad problems whose correct solution depends not on the application of legal precedents, but upon a practical acquaintance with the details of railroad management. 
In advance of judicial decisions, it is difficult to say whether the Circuit Courts will maintain or deny their original jurisdiction to issue such injunctions. This much, however, may be argued in favor of the power. The remedies prescribed by the act itself, it is expressly declared by Section 22, are not "in any way to abridge or alter the remedies now existing at common law or by statute, but the provisions of this act are in addition to such remedies." Section 716 of the Revised Statutes declares that "the Circuit Courts shall have power to issue all writs not specially provided for by statute, which may be necessary for the exercise of their respective jurisdictions and agreeable to the usages and principles of law." The inadequacy of even punitive damages as a remedy against continuing the excessive charges or future discriminations, together with the policy of equity to prevent a multiplicity of suits, would seem to furnish a substantial basis for the jurisdiction without a previous order of the Commission. But it is unnecessary to determine which of these alternatives will result, as both would be equally desirable from a mercantile standpoint, especially since amendatory legislation will obviate both difficulties.

II. Is the Act of February 4, 1887, unconstitutional as involving a delegation of legislative power? It is postulated that the constitutional power to regulate commerce includes the power to fix railroad rates. Chief Justice MARSHALL, in Gibbons $v$. Ogden, construed the words "power to regulate" as follows: "This power, like all others vested in Congress, is complete in itself, may be exercised to its utmost extent, and acknowledges no limitations other than are prescribed in the Constitution." And in the same case Mr. Justice JoHnson declared that "the power is the same as that which previously existed in the sovereign States, and that the power of a sovereign State over commerce is the power to limit and restrain it at pleasure."

The only question open, therefore, is, whether the Commission may constitutionally exercise this power. That the act to regulate commerce conferred upon the Com- 
mission the power to fix rates is a logical conclusion from the words of Section I2 of the act: "The Commission is hereby authorized and required to execute and enforce the provisions of this act." If, then, the act declares, as in Section I, that " all charges made for any services rendered, or to be rendered, in the transportation of passengers or property, shall be reasonable and just, and every unjust and unreasonable charge for such services is prohibited and declared to be unlawful," the Commission must either have the power to declare what are just rates, or the absurdity follows that any reduction whatever is a compliance with the order, and a just and reasonable rate can only be obtained by a shipper by successive litigations. While it is true that "one of the set maxims of constitutional law is that the power conferred upon the Legislature to make laws cannot be delegated by that department to any other body or authority," 1 nevertheless this maxim is subject to several exceptions and modifications, and is rather a fiction of political science than a precise principle of law. In LockE on Civil Government, ${ }^{2}$ a discriminating analysis reveals the fact that the functions of the three departments of government cannot be thus logically differentiated, and numerous legal decisions establish that the functions of one department may constitutionally partake of the character of the others. Municipal governments illustrate, perhaps, the first class of exceptions, but a no less important exception is made in the case of railroad commissions. In Chicago \& N. W. Railroad v. Dey et al., ${ }^{3}$ an injunction was asked for to restrain the Commissioners from enforcing their schedule of rates because the power to "fix rates for common carriers" is a legislative function and cannot be delegated to commissioners. The Court held that there was no delegation, as the fixing of rates was merely an administrative function.

"It seems to us that the authority and discretion conferred upon this Commission is of the latter kind. The

${ }^{1}$ Cooley on Constitutional Limitations, I $_{37}$.

${ }^{2}$ Sec. I42.

${ }^{3} 4$ Ry. and Corp., L. J., 465. 
Legislature enacts that all freight rates and passenger rates shall be just and reasonable, and what are equal and reasonable rates is a question depending upon an infinite and ever-changing variety of circumstances. We are referred to no case where the grant of such authority and discretion to a board or commission has been held invalid as the delegation of legislative power, but numerous decisions sustain the validity." I In Commission v. Milwaukee \& St. Paul Railroad the Supreme Court of Minnesota used this language: "The difference between the departments undoubtedly is that the legislative makes, the executive executes and the judiciary construes the law ; but the maker of the law may submit something to the discretion of the other departments, and the precise boundary of this power is a subject of difficulty, a delicate inquiry into which a court will not unnecessarily enter." 2

In Tilley $v$. Savannah, Florida \& Western Railroad, ${ }^{3}$ the Court sustained the constitutionality of the Commission and said: "The true distinction, therefore, is between the delegation of power to make a law which necessarily involves a discretion as to what it shall be and the conferring an authority or discretion as to its execution by exercise under and in pursuance of the law. The first cannot be done; to the latter no valid objection can be made." "4

III. Is it constitutional for the Commission to condemn as znreasonable and unjust rates charged by common carriers of interstate commerce so long as those rates are not greater than those permitted to be charged by the carrier corporations in their charters which they have obtained from State legislatures?

The inquiry under this head would naturally be directed to two points: (r) Has the State Legislature used language equivalent to a renunciation of all future interference, and

1 To the same effect are Tilley $\nu$. Savannah, Florida \& Western Railroad, 5 Fed. Rep., 658 ; State $e x$ rel. Commission $v$. Chicago, Milwaukee \& St. Paul Railroad, 37 N. W. Rep., 782.

2 Citing Wayman $v$. Southard, ro Wheaton, 46.

${ }^{3} 5$ Fed. Rep., 64r.

4 See also Georgia Banking Co. v. Smith, I28 U. S., I8r. 
therefore established a contractal relation between the State and the carrier? (2) Does the subject-matter of the contract lie within the domain of a State legislature? It is clear that even when the terms of the charter constitute a positive contract between the legislature and the railroad corporation, such an agreement is binding only upon the State itself which entered into the contract, and necessarily imposes no obligation upon another sovereign power in respect to the corporation when within the latter's dominion. Hence, in cases arising under the Interstate Commerce Act, all inquiry as to the exact meaning of the "terms of exclusion" employed in State charters is dispensed with. The power of Congress over interstate commerce, as has been said, is an exclusive power.' Consequently, even in the absence of Congressional regulation, no State could have entered into more than a mudum pactum with reference to its future regulation of interstate commerce. However binding such a contract might be as to a State's internal commerce, it imposes no obligation whatever upon Congress. Nor can the fact that a corporation is chartered by all of the States through which it transports interstate traffic, and that these charters constitute contracts in respect to the maximum rates to be charged, authorize the railroad to charge any rates within the maximum, if those rates are condemned by the Federal Government.

In Norfolk \& Western Railroad Co. v. Pennsylvania, ${ }^{2}$ Mr. Justice LAMAR clearly states this doctrine: "Whenever a commodity has begun to move as an article of trade from one State to another, commerce in that commodity between the States has commenced. The fact that several different and independent agencies are employed in transporting the commodity, some acting entirely in one State and some through two or more States, does not in any respect affect the character of the transaction, and to the extent to which each agency acts in that transaction it is subject to the regulation of commerce." States of the Union having once parted with the power to regulate com-

${ }^{1}$ Leisy v. Hardin, 135 U. S., roo.

${ }^{2}$ I36.U. S., II4. 
merce among the several States by ratifying the Constitution, and having conferred that power upon Congress exclusively, all charters subsequently granted must conform to this organic law, and no State charters can, therefore, confer upon common carriers exemption in the smallest degree from the regulation by Congress of their interstate traffic.

IV. If the final and absolute power to fix rates were conferred on the Interstate Commerce Commission, would the exercise of such a power involve a deprivation of property "without due process of law?"

The cases of Chicago, etc., Railroad Co. $v$. Minnesota, ${ }^{1}$ and Minneapolis \& Eastern Railroad Co. v. Minnesota, ${ }^{2}$ are instructive upon this point. The former case came before the Supreme Court upon a writ of error to review a judgment of the Supreme Court of Minnesota awarding a writ of mandamus against the Chicago, Milwaukee \& St. Paul Railroad Co. The act of Minnesota, under which the controversy arose, provided that in case the "Commission shall find, at any time, that any part of the tariffs of charges filed and published by common carriers is in any respect unequal or unreasonable, it shall have the power, and it is authorized and directed to compel any common carrier to change the same and to adopt such charge as the Commission shall declare to be equal and reasonable."

The company having refused to adopt the schedule fixed by the Commission, the latter sought to enforce compliance by mandamus. The United States Supreme Court decided (Mr. Justice BLATCHFORD delivering the opinion) that the Minnesota statute in effect deprived the company of its right to a judicial investigation by due process of law. From this opinion Justices BRADLEY, GRAY and LAMAR dissented. Its importance in application to the Interstate Commerce Act or to proposed amendments to the same cannot be exaggerated. It must be admitted that as the Minnesota statute made no provision for a hearing, for a summons or for notice to the company, and afforded no opportunity for it to introduce witnesses before the Com-

$\mathrm{I}_{34}$ U. S., $4 \mathrm{I} 8$.

$2 I d ., 467$. 
mission, while the Interstate Commerce Act secures all these rights to the carrying companies, the two cases are not entirely parallel, but the point in the one sufficiently resembles that in the other to make this decision a controlling authority and a valuable guide to constitutional legislation. The conclusion was reached in the preceding section of this article that conferring upon the Commission the final and absolute power of making rates was not a delegation of legislative power; but the question now arises whether conferring power upon the Commission to determine what are just and reasonable rates is not an unconstitutional transfer of judicial functions to a non-judicial, administrative body. The Act of Congress, making all charges just and reasonable, was, properly speaking, a Iegislative act declarative of the common law. ${ }^{1}$

The determination of the two questions which naturally follow (I) what is a just and reasonable rate in the absence of a definition by the legislature, and (2) is any given rate just and reasonable, is clearly the function of the judicial department. It will be remembered that the distinction was made under the head of the delegation of power between declaring what the law shall be and applying a welldefined law to particular facts. In the latter case, there is clearly no legislative power exercised; but when a commission undertakes to say what is a just and reasonable rate, what are like and contemporaneous services, what are substantially similar circumstances and conditions, it attempts not merely to apply the law, but to ascertain primarily what the law is. The Interstate Commerce Act requires to be expounded before it can be applied, and to expound the Federal law is the business of the Federal Courts. The case of the Chicago, etc., Railroad Co. $v$. Minnesota is a direct authority upon the point that a legislature cannot confer the final determination of a question of law upon a railroad commission. The Court used the following language: "The question of the reasonableness of a rate of charge for transportation by a railroad company, involving as it does the element of reasonableness both as regards the

1 Menacho v. Ward, 27 F. R., 29. 
company and as regards the public, is eminently a question for judicial investigation requiring due process of law for its determination."

The dissenting opinion of Mr. Justice BRADLEY, who admits that "what is a reasonable charge is pre-eminently a legislative question" and not a judicial one, admits that "where the Legislature declares that the charges shall be reasonable, or, which is just the same thing, allows the common-law rule to that effect to stand, and leaves the matter there, then resort may be. had to the courts to inquire judicially whether the charges are reasonable." But what practical difference is there between this supposed case and the one under discussion? In making the decision of the Commission final, the Legislature doess not obviate the fact that they have enacted a law and referred it for interpretation to a mere creature of the legislative department. To shut off all judicial inquiry into the meaning of the act would be to extend the prerogative of an administrative body decidedly beyond their constitutional limits. The distinction is patent between the right of the Legislature to enact, in the first.instance, that no rate shall exceed a certain maximum per ton per mile, and an enactment that all rates shall be just and reasonable. In the first case there is no question for the courts to decide, but in the second case the question is eminently a judicial one. Between these two cases lies the case under discussion, viz., where the Legislature empowers a commission to determine finally and absolutely what are just and reasonable rates.

Since, however, in the second case, the Legislature cannot define the meaning of just and reasonable rates except by the enactment of another statute, it is difficult to see how a commission can finally construe those terms without usurping either judicial or legislative functions. It may, indeed, be, as is hereafter contended, that the term "reasonable rates" is not capable of a general definition, but will vary according to the peculiar facts of each particular case. Nevertheless, even this construction can come only from the judicial department. 


\section{General Conclusions.}

From an examination of the foregoing constitutional questions arising in the suits of the Interstate Commerce Commission, it appears that while expediency dictates an amendment of the act, there are certain well-defined limitations within which amendments must be made to render them constitutionally effectual. Such a scheme of amendment as that proposed by the Commission itself, in its Fourth Annual Report," viz., that "on the hearing in the Circuit Court all findings of fact made by the Commission shall be deemed and held conclusive, unless found by the Court on the record to be erroneous, and all questions of law arising in said proceeding shall be heard, considered and determined by said Circuit Court as though they had not been heard, considered and determined by the Commission in any manner whatever," while designed to make the findings of fact of the Commission not merely prima-facie evidence, but conclusive evidence, would not effect that result.

What is a question of law, and what is a question of fact? In the past the effort of the Commission has been to treat all questions as questions of fact, while, on the other hand, the Circuit Court have reached a conclusion different from the decision of the Commission by treating the point at issue as merely a question of the judicial interpretation of the statute. Thus in the case of the Interstate Commerce Commission $v$. Baltimore and Ohio Railroad, ${ }^{2}$ it was found as a fact by the Commission that "party-rate tickets" were a style or variety of tickets differing from excursion, commutation or mileage tickets (the three exceptions enumerated in the section prohibiting discriminations), and, therefore, the conclusion of law followed that "partyrate tickets" were illegal; but the Circuit Court treated the question, are "party-rate tickets" a discrimination? not as a mixed question of law and fact, but as purely a question of law. They construed the word "commutation"

1 Pp. 20, 2 I.

243 Fed. Rep., 48. 
in the act to be a generic term sufficiently broad to include the particular variety known as "party-rate tickets."

Plainly, the questions, what in any given case is a reasonable or unreasonable rate, what are substantially similar circumstances and conditions, what is undue or unreasonable preference or advantage, what is undue or unreasonable prejudice or disadvantage, are all mixed questions of law and fact which have never received either legislative or judicial definition. Whether a particular case falls within the line is, of course, a question of fact; but inasmuch as the line between questions of law and fact cannot be accurately drawn for all cases, and as the judicial power of the United States extends to all cases arising under the laws of the United States, the suggestions of the Commission, if adopted, would simply perpetuate the present undesirable practice of trying every question twice, first as one of fact and then as one of law. Another constitutional limitation which must be borne in mind by the legislator proposing amendments to the Interstate Commerce Act is, that the judicial power of the United States is vested by the Constitution in one Supreme Court and in inferior courts whose judges hold office during good behavior. No body of men, therefore, can render an absolute and final decision upon questions of law within the province of the judiciary unless those men constitute an inferior court and hold office during good behavior. It is apparent that the task of finally and authoritatively defining the terms of the Interstate Commerce Act is judicial in its character, and one that can never be constitutionally final and absolute when performed by commissioners whose tenure is only for a term of years. Enough has been said to prove the proposition that future legislation must proceed upon the plan of referring all questions arising under the Interstate Commerce Act to a constitutionally organized Federal Court.

A system of procedure which would refer to the Federal Courts all questions arising under the Interstate Com-

1 See, in this connection, Samuels $v$. L. \& N. R. R. Co., 3I Fed. Rep., 58 ; United States $v$. Tozer, 2 I. C. C. Rep., 540; 39 Fed. Rep., 369. 
merce Act would prevent the delays and embarrassments of the present practice. The judgments of such a court would necessarily be conclusive as to the facts found and nct merely prima-facie evidence. No question could then arise as. to the delegation of legislative power, and the process of law, in the most comprehensive sense, would be secured.

Two alternatives, then, present themselves to the legislator: (I) shall the idea of a commission be discarded and the enforcement of the Interstate Commerce Act be left exclusively to the Federal Courts ; or (2) shall Congress confer judicial powers upon the Interstate Coinmerce Commission, invest them with tenure for life, dependent only upon good behavior?

If the enforcement of the Interstate Commerce Act required merely the application of certain well-defined principles of law to the various cases arising under it, no plan could be more desirable than to refer the entire matter to Federal judges, learned in the law. But a slight reflection shows that questions concerning the reasonableness of interstate railroad rates, while they undoubtedly demand the exercise of judicial powers, in the interpretation of the . statute, require also an intimate acquaintance with the complex details of the business of railroad transportation. For example, take the question, what in any particular case is a reasonable rate? To answer this question properly a court cannot look to precedent or authority, because there is none. Nor is any one criterion adequate. You cannot determine the reasonableness of a rate exclusively by the weight or by the bulk or by the value of a commodity transported. To impose a certain charge per ton per mile for all articles would effectually prevent those whose value is small in proportion to their weight from ever reaching the market. So, too, if bulk were the only determinant. It may be said that the minimum charge on any commodity should be the cost of carrying it, plus a fair profit to the carrier for the service. But this theory disregards the fact that the cost of transportation will vary according to weight and bulk, and thus heavier and larger articles will be charged more in propor- 
tion to their value than smaller and lighter ones. To ascertain, therefore, what is a just and reasonable rate for any particular commodity, the entire schedule of rates must be considered, and such a classification adopted as will impose heavier rates upon articles whose value is greater in proportion to their bulk or weight instead of placing upon any traffic a greater burden than it can bear." But, again, in making a just and reasonable rate, one must consider the interest of the railroad company as well as that of the shipper; the cost of construction, of running expenses, of necessary improvements, of the introduction of new appliances, are all elements in the problem. It is clearly impossible to promulgate any general rule as to the amount of income to be devoted to these purposes, just as it is impossible to say what dividends on the stock or what interest on the bonds and mortgages railroads in general must earn enough to pay. It has been said that rates should never be fixed so low that the company cannot pay interest upon its obligations and some dividends to its stockholders. But if no rates were excessive so long as the entire income of a road was not sufficient to pay dividends, the shipper would be at the mercy of bankrupt railroads which never have and never will pay dividends. By charging ordinary rates such railroads are nevertheless able to pay running expenses, and thus serve the interests of the public. Nor would it be sufficient for the Circuit judges to possess a knowledge of the traffic and finances of merely the defendant corporation. They must not only have the information possessed by a general freight agent, a general passenger agent, and a board of directors of the railroad whose rates are the subject of inquiry, but a similar acquaintance with the business of rival carriers. No railroad can be considered singly, but only as part of the general transportation system of the country. A rate, to be just and reasonable, must have regard to the interests not only of the shipper and carrier, but also to the interests of competing roads. Without pressing the inquiry further, the conclusion is evident that the powers necessary to a wise administration of the

'See preceding article on "The Anthracite Coal Situation." 
Interstate Commerce Act should be confided by Congress to a body of men who can devote to the investigation of these questions of transportation their exclusive time and attention, and who will render decisions based upon the exercise of a sound business discretion.

The Federal judges cannot devote the time to these questions which their complexity and importance demand. Even if they could give such subjects adequate attention, the diversity of their decisions in different circuits upon practically similar facts would prevent a uniform development of the law and furnish no practical guide for business men. The extra delay consequent upon increasing the amount of business now before the courts is a substantial objection to referring to their decision such questions as those concerning rates, in which a decision must be summarily rendered and enforced, or the delay practically defeats the remedy.

Without entering into minute details, there are several points which should commend themselves to a legislator when drafting an amendinent to the existing law. Experiment has shown that three classes of questions arise under the Interstate Commerce Act : $(a)$ pure questions of fact, e. g., whether a rebate has been given, whether a less sum has been charged to one shipper than to another, or what are the annual earnings of a corporation; $(b)$ mixed questions of fact and law, e.g., what is a reasonable rate, what are substantially similar circumstances and conditions, what is a like and contemporaneous service; $(c)$ pure questions of law, e.g., whether express companies doing business over the roads of common carriers are subject to the provisions of the act, or questions of construction of contracts or leases.

A properly constructed judicial system designed to enforce the act to regulate commerce would clothe the Commission with judicial powers and confer upon it exclusive jurisdiction to entertain suits for damages, or enforce its decisions by injunction or other summary process in all cases arising under the act. The final decision of all mere questions of fact should be confided to the Commission with 